\title{
ICT Integration into Science Education and Its Relationship to the Digital Gender Gap
}

\author{
Ascensión Palomares-Ruiz *, Antonio Cebrián D, Emilio López-Parra \\ and Eduardo García-Toledano
}

Department of Pedagogy, Universidad de Castilla-La Mancha, Plaza de la Universidad, 3, 02071 Albacete, Spain; Antonio.Cebrian@uclm.es (A.C.); Emilio.LopezParra@uclm.es (E.L.-P.); toledanoeg@gmail.com (E.G.-T.)

* Correspondence: Ascension.Palomares@uclm.es; Tel.: +34-9675-992-00

Received: 23 May 2020; Accepted: 29 June 2020; Published: 30 June 2020

\begin{abstract}
The objective of the research is to know whether the use of technologies in the teaching of sciences, in the face of more traditional methods, influences gender differences, justifying the low enrolment of women in technical careers. The study was developed using a pretest-posttest quasi-experimental method through a nonequivalent control group with traditional methodology and common instruments such as the textbook, while in the experimental group, methodologies based on the management of ICT tools were made. We make a quantitative contrast of the impact on learning, considering the advantages and disadvantages of using technologies in science teaching, versus more traditional methods. The experimental group showed a higher motivation, being seen in the impact on better learning scores compared to the control group. We found that women scored higher than men in both pretest and posttest. We conclude by emphasizing the desirability of a transformation of science teaching methodologies by using ICT tools that allow more visual, intuitive, and collaborative work, with greater involvement of students.
\end{abstract}

Keywords: digital gender gap; ICT-mediated learning; connectivism; network learning; sustainable development

\section{Introduction}

The current situation caused by Covid-19 and the global health emergency is causing an accelerated transit from face-to-face education to online education, such as the Chinese government-designed "School's Out, But Class's On" program, implemented on 28 February 2020, where 270 million students, mostly in primary and secondary education, began receiving online classes [1]. This program is not just a response to the pandemic, but a total change of the Chinese educational model in which it has avoided replicating traditional teaching methods. It establishes coordination with state television for the broadcast of teaching content that complements the official curriculum. It enhances the individualization of teaching. It coordinates and adapts the characteristics of digital platforms with the real needs of students. In addition, the traditional length of one hour has been changed to $20 \mathrm{~min}$ of class and free time for students to prepare for classes in advance. It provides courses adapted to each level on precautionary measures before Covid-19, trying to complement the work of health facilities. It gives priority to digital content, avoiding the purchase of materials that would increase the economic burden of families. It creates a state repository of online teaching resources accessible to teachers from anywhere and at any time. However, a minority of teachers have continued masterclasses through video calls. It should be recalled that, in order for an educational paradigm shift [2] to happen, the stage of "integration" of emerging technologies with traditional education systems must be overcome, and emerging pedagogies are underpinned by approaches such as cognitivism, constructivism, and significant learning. In addition, there are other new crystallized approaches, 
following the advent of the web and the Internet, such as self-regulated learning, rhizomatic learning, LaaN theory, connectivism, and peer learning, which have not, in many cases, changed traditional educational practices and which, in the current situation, can accelerate the transformation of the way we work in the classroom, putting the focus on learning rather than in learning, and on the student as an active and nonpassive subject of his own learning and not on the teacher [3-5].

The United Nations General Assembly approved the 2030 Agenda for Sustainable Development in 2015. This action plan aims to drive the international community's commitment to build a better world. Therefore, recognizing the need to work to eliminate inequalities among men and women, as a human right, promotes the obligation of the international community to ensure that gender equality and the empowerment of all women and girls is a reality, through Specific Objective [5], and cross-cutting in other objectives. In particular, it is intended to improve the use of technology and, in particular, information and communications technology to promote women's empowerment [6].

On the other hand, numerous research shows that cultural differences between genders have driven, to a lesser extent, women towards enrolment in technical careers [7-10], having declined their presence in the last two decades [11-15]. Some of these studies have pointed out that technology and computers are often considered male tools [16-20]. One of the possible factors of such rejection may be that women use video games less for their leisure, being one of the gateways to technology [17,21-28]. Reasonably, the digital gender gap may be related to the low enrolment of women in technical careers. As can be seen, Table 1 and Figure 1 reflect Eurostat data [29] regarding the distribution of students in the undergraduate studies by field of study and gender, appreciating that women decide on careers related to health, education, and the services sector, while men decide on technical careers such as engineering and computer science, where women reach just $10 \%$.

Table 1. Students enrolled in tertiary education.

\begin{tabular}{|c|c|c|c|c|c|c|c|c|c|c|c|}
\hline Acronym & $\begin{array}{c}\text { GEO/TIME } \\
\text { European } \\
\text { Union-28 } \\
\text { Countries }\end{array}$ & \multicolumn{2}{|c|}{2013} & \multicolumn{2}{|c|}{2014} & \multicolumn{2}{|c|}{2015} & \multicolumn{2}{|c|}{2016} & \multicolumn{2}{|c|}{2017} \\
\hline EDU & Education & 21.8 & 78.2 & 22.2 & 77.8 & 21.3 & 78.7 & 21.6 & 78.4 & 21.9 & 78.1 \\
\hline $\mathrm{HaW}$ & $\begin{array}{l}\text { Health and } \\
\text { Welfare }\end{array}$ & 27.7 & 72.3 & 27.9 & 72.1 & 28.8 & 71.2 & 28.9 & 71.1 & 28.7 & 71.3 \\
\hline SJI & $\begin{array}{l}\text { Social sciences, } \\
\text { Journalism and } \\
\text { Information }\end{array}$ & 37.5 & 62.5 & 37.5 & 62.5 & 36.8 & 63.2 & 36 & 64 & 36.1 & 63.9 \\
\hline Ball & $\begin{array}{c}\text { Business, } \\
\text { Administration } \\
\text { and Law }\end{array}$ & 43.9 & 56.1 & 44.7 & 55.3 & 44.3 & 55.7 & 44.5 & 55.5 & 45.5 & 54.5 \\
\hline NMS & $\begin{array}{c}\text { Natural sciences, } \\
\text { Mathematics and } \\
\text { Statistics }\end{array}$ & & & & & 50.1 & 49.9 & 50 & 50 & 50 & 50 \\
\hline $\mathrm{Be}$ & Services & & & 82.4 & 17.6 & 52.7 & 47.3 & 52.7 & 47.3 & 52.8 & 47.2 \\
\hline EMC & $\begin{array}{l}\text { Engineering, } \\
\text { Manufacturing, } \\
\text { and Construction }\end{array}$ & & & & & 73.8 & 26.2 & 74 & 26 & 73.9 & 26.1 \\
\hline ICT & $\begin{array}{l}\text { Information and } \\
\text { Communication } \\
\text { Technologies }\end{array}$ & 82.6 & 17.4 & 82.4 & 17.6 & 81.9 & 18.1 & 81.7 & 18.3 & 82 & 18 \\
\hline
\end{tabular}

Source: Own elaboration adapted from Eurostat [29]. 


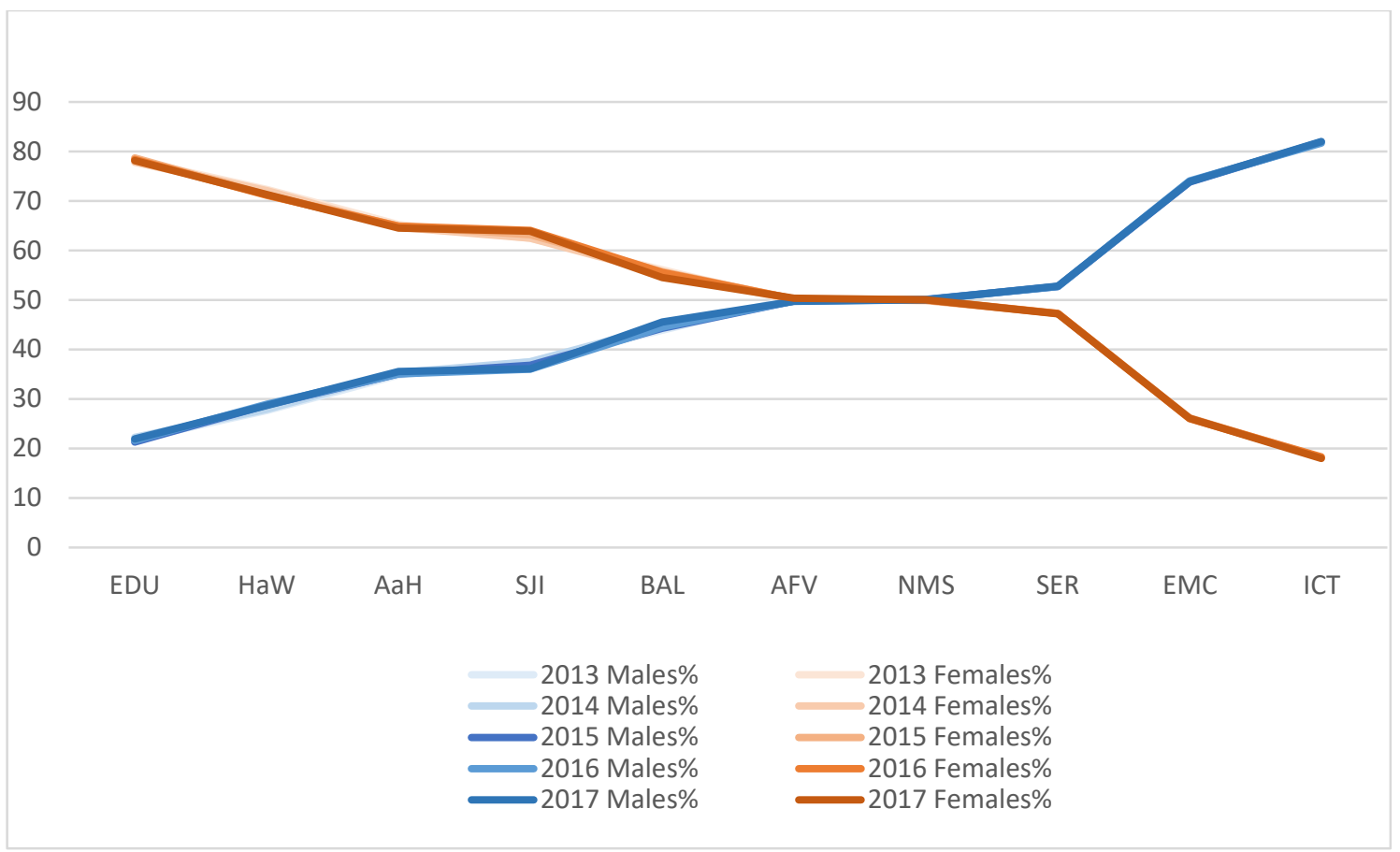

Figure 1. Students enrolled in tertiary education. Source: Own elaboration adapted from Eurostat [29].

The research presented in this article was carried out in the 2018-2019 academic year, with the aim of knowing whether the use of technologies in the teaching of sciences, versus more traditional methods, influences gender differences, justifying the low enrolment of women in technical careers. In order to verify, through inferential statistical analysis, the objective of the research, a Didactic Unit (DU) was developed for the students of first compulsory secondary education (ESO) of an institute of secondary education (IES) of the province of Albacete in the autonomous community of Castilla-La Mancha, in Spain. The control group delivered the DU in a more traditional way with instruments such as master classes and textbooks, while the experimental group employed a DU-ICT that included a treasure hunt and a WebQuest.

\section{Materials and Methods}

A quantitative methodology with a quasi-experimental design was used, as it was intended to determine causal relationships between the variables involved in the study, seeking an explanation of the extent to which the variations recorded in dependent variables are a consequence of the manipulation carried out on the independent variable using inferential statistical techniques. We also intended for the circumstances in which the investigation was carried out to be similar to those found in the normal teaching of the science subject in the 1st ESO of the IES, where the research took place. Therefore, two groups of students that were already constituted were selected without being able to assign the students randomly. This decision reduces the external validity of the investigation, so it cannot be said that the results obtained were totally generalized [30].

To try to control any initial disparities between the control group and the experimental one that could affect the results, a pretest was established to verify that the means between the two groups were similar, to ensure the internal validity of the study. Another aspect that needed to be monitored was the influence of teacher education on both groups. In order to be able to reduce it, it was decided that it would be the same teacher who intervened in both groups [30]. 
The research was carried out using a pretest-posttest quasi-experimental methodology through a nonequivalent control group. It was considered that the "learning effect" would not be decisive because the period of time between the completion of the pretest and the posttest would be a period of only 6 weeks long enough [30].

\subsection{Variables}

The variables involved in the research were as follows.

Dichotomous qualitative independent variable: working methodology with two values- $\mathrm{N}$ (traditional DU) and S (DU-ICT). Another independent dichotomous variable that was included in the research was gender (GEN), with two values-female (F) and male (M). Continuous quantitative dependent variables: academic performance of students in both pretest (PRE), and posttest (POS). A new variable called improvement (MEJ) was determined to calculate the improvement of each student between the score reached in the posttest and the score achieved in the pretest.

Similarly, other possible foreign variables that could affect the research's findings were controlled by the selected design and were also considered. The effect of the teacher on each of the groups was not decisive because the teacher of the control group and the experimental group was the same person. In addition, the only distinction in teaching in both groups was the use of an ICT methodology in the DU developed in the experimental group, while in the control group, the DU would be developed by the teacher using a traditional methodology focused on textbooks and masterclasses.

\subsection{Population and Sample}

The population of the research was constituted by the students of the first course of ESO of an IES of the province of Albacete in the autonomous community of Castilla-La Mancha, in Spain, with a size of 141 students. The students were distributed in 6 different groups, with two of the six groups participating in the research. Group $1 \mathrm{~F}$ was chosen randomly for the experimental group and group $1 \mathrm{C}$ for the control group. The sample consisted of 46 students, 23 in the control group and another 23 in the experimental group. Students were already distributed in groups prior to research, so they could not be randomly assigned and, therefore, were not equivalent groups. These circumstances were not decisive since the objective of the research was not to be able to generalize the results but to try to understand the potential relationships between the variables of the study.

\subsection{Test Reliability Analysis}

To calculate reliability in the sense of stability and accuracy of the data, the use the Cronbach alpha formula, which was calculated through the data obtained when taking the questionnaire in the sample studied, was preferred. The results in both pretest (PRE; 0.871) and posttest (POS; 0.899), being greater than 0.80 , can be considered as high or very high reliability, so that the test can be accepted as consistent internally. The homogeneity of the items was also analyzed by testing the element-total correlation, and it was proven that the deletion of any of the items substantially improves the Cronbach alpha. The Google Docs form used as a questionnaire in both the pretest and posttest can be found at https://forms.gle/VFyyarFgeJ8A1WUP7. 


\subsection{Educational Intervention}

We sought to make the educational intervention in the control group as similar as possible to that carried out in the experimental group. As noted above, the teacher was the same person for the two groups involved in the research, with the purpose of making teaching in both groups as similar as possible. It was ensured that the only difference was the use of an ICT methodology employing a DU-ICT that included a treasure hunt and a WebQuest in the experimental group, and a more traditional methodology focused primarily on masterclasses and textbooks in the control group. The rest of the teaching methodologies were similar in both groups: providing equivalent content, carrying out similar teaching activities, and carrying out identical evaluation tests. We sought to employ an active methodology while maintaining the pedagogical principles of cooperative, collaborative and autonomous work and enhancing critical reflection through exchanges of ideas that encouraged discussion on various issues. The method of problem-solving was used to encourage the students to try to solve problems by explaining the resolution processes employed to their classmates, using appropriate language, and encouraging at all times that students should meet and discuss the different solution procedures. The teacher encouraged, guided, and motivated students by using both material and virtual manipulative resources, and also taking into account attention to diversity by preparing reinforcement and expansion activities. The teaching unit can be found at https://drive.google.com/file/d/1vlox83osPg1AsASymXF-If-Qh-BXroGr/view?usp=sharing.

\section{Results}

To try to respond to the research problem, it was checked whether the null hypothesis could be rejected. H0: Mc-Me-0, where Mc and Me were the respective sample stockings of the qualifications obtained by the students in the experimental and control groups. We checked, through statistical evidence, whether the null hypothesis could be rejected, accepting that there were significant differences between the groups being compared [30]. On the other hand, the degree of significance had to be set, which implies the probability of error that could be assumed in rejecting the null hypothesis. As usual, in educational research, a $p$-significance level of 0.05 was assumed. The inferential statistical technique used was the Kolmogorov-Smirnov normality test with the correction of Lilliefors, and as the sample was slightly less than 50 . The Shapiro-Wilk normality test was also used to ensure the normality required in the use of parametric tests. The Levene test was also used to verify homoscedasticity in the comparison of variances. The ANOVA general linear model multivariant test was used for the comparison of means between independent samples with the SPSS 24 statistical package.

In the ANOVA test of 1 independent sample factor with respect to the ICT variable, as can be seen in Table 2, the significance levels in both pretest (0.923), and posttest (0.139) are greater than $(0.05)$, so those means can be considered equal for the chosen confidence level $95 \%$, and we must accept the null assumption of the equality of means, $\mathrm{H0}$ : Mc-Me-0, and reject the alternative hypothesis $\mathrm{H} 1$ of the difference of means between the control and experimental groups. However, with respect to the variable improvement as the significance level (0.002) was less than (0.05), we have to reject the null hypothesis of equality of means, $\mathrm{H} 0$ : Mc-Me-0, and accept the alternative hypothesis $\mathrm{H} 1$ of the difference of means between the control and experimental groups. Regarding the gender (GEN) variable, as the significance levels in both the 0.815 pretest and the posttest $(0.792)$ and in the variable improvement (0.888) are greater than (0.05), it would, therefore, have to be assumed that, although the women's scores are slightly higher than that of men, both in pretest and posttest and slightly lower in the improvement MEJ variable, there are no statistically significant gender differences. 
Table 2. Test ANOVA gender (GEN)-TIC overall linear model multivariant.

\begin{tabular}{|c|c|c|c|c|c|c|}
\hline Origin & Dependent Variable & $\begin{array}{l}\text { Type III } \\
\text { Sum of } \\
\text { Squares }\end{array}$ & G1 & $\begin{array}{c}\text { Quadratic } \\
\text { Average }\end{array}$ & $\mathbf{F}$ & $\begin{array}{c}\text { It's Getting } \\
\text { You out of } \\
\text { Here }\end{array}$ \\
\hline \multirow{3}{*}{ Model corrected } & PRE_D & $0.844^{\mathrm{a}}$ & 3 & 0.281 & 0.055 & 0.983 \\
\hline & POS_D & $16.951^{b}$ & 3 & 5.65 & 0.836 & 0.482 \\
\hline & MEJ_D & $17.474^{\mathrm{c}}$ & 3 & 5.825 & 4.858 & 0.005 \\
\hline \multirow{3}{*}{ Intersection } & PRE_D & 371.128 & 1 & 371.128 & 72.38 & 0 \\
\hline & POS_D & 1.181 .964 & 1 & 1.181 .964 & 174.781 & 0 \\
\hline & MEJ_D & 228.464 & 1 & 228.464 & 190.528 & 0 \\
\hline \multirow{3}{*}{ Gen_F } & PRE_D & 0.285 & 1 & 0.285 & 0.056 & 0.815 \\
\hline & POS_D & 0.476 & 1 & 0.476 & 0.07 & 0.792 \\
\hline & MEJ_D & 0.024 & 1 & 0.024 & 0.02 & 0.888 \\
\hline \multirow{3}{*}{ TIC_F } & PRE_D & 0.048 & 1 & 0.048 & 0.009 & 0.923 \\
\hline & POS_D & 15.391 & 1 & 15.391 & 2.276 & 0.139 \\
\hline & MEJ_D & 13.721 & 1 & 13.721 & 11.442 & 0.002 \\
\hline \multirow{3}{*}{ Gen_F* TIC_F } & PRE_D & 0.47 & 1 & 0.47 & 0.092 & 0.763 \\
\hline & POS_D & 2.941 & 1 & 2.941 & 0.435 & 0.513 \\
\hline & MEJ_D & 5.763 & 1 & 5.763 & 4.806 & 0.034 \\
\hline \multirow{3}{*}{ Error } & PRE_D & 215.355 & 42 & 5.127 & & \\
\hline & POS_D & 284.027 & 42 & 6.763 & & \\
\hline & MEJ_D & 50.362 & 42 & 1.199 & & \\
\hline \multirow{3}{*}{ Total } & PRE_D & 597.28 & 46 & & & \\
\hline & POS_D & 1530.3 & 46 & & & \\
\hline & MEJ_D & 309.34 & 46 & & & \\
\hline \multirow{3}{*}{ Total corrected } & PRE_D & 216.198 & 45 & & & \\
\hline & POS_D & 300.977 & 45 & & & \\
\hline & MEJ_D & 67.837 & 45 & & & \\
\hline
\end{tabular}

\section{Discussion}

Predictably, in the pretest, the experimental group (2.069) and the control group (2.839) obtained similar means, not resulting in a statistically significant difference.

In the posttest, the experimental group, formed by class group 1F, obtained an average of 5.713, higher than that of the control group (4.626) consisting of class group 1C; this difference was statistically significant, which allowed us to answer affirmatively to the research question.

Importantly, women achieved a higher average (7.998) than men (7.786); this difference in academic performance was not statistically significant. However, the improvement of women (2.265) was lower than that of men (2.325), which allows us to glimpse an emerging digital gender gap that, linking to Eurostat [29], girls have more difficulties than boys in managing ICTs expertly, which is probably one of the factors related to them opting for careers related to education, health, and services in the future.

\section{Conclusions}

Recent research shows that the first digital gender gap tends to disappear, with a tendency to equate the number of ICT users of both genders [31,32]. However, the second digital gender gap in today's society $[16,33,34]$, which is determined by gender differences in ICT skills, remains present, showing some influence-only $17 \%$ of students enrolled in computer engineering in Europe are women [35-37].

It is estimated that the problem is the result of certain social practices that contribute to a meager preference of women for technology, which leads to male dominance in the areas of work where new technologies are developed [31-33]. 
The results of the research encourage us to recommend the creation of more conducive contexts for women by transmitting female models in the field of technology, as well as promoting training actions aimed at improving the teaching-learning processes supported by new technologies among teachers of schools and institutes [38-42].

Likewise, it should be emphasized that although the handling of computers as a tool of communication and relationship is sufficiently even between boys and girls, coinciding with the results obtained in other research [43-47], it is not emerging in the same way in the use of technological leisure, such as in the field of video games. It is worth noting that numerous studies have linked the digital gender gap to girls' different use of video games, leading to a contraction in women's professional and educational opportunities $[21,46,48]$.

It has been shown that, in the face of a global health emergency, there is a translation from face-to-face teaching to online education, generating the need for a change in educational paradigm in which women expertly overcome difficulties in the use of ICTs. Therefore, the public authorities, with the adoption of the relevant equity policies, must ensure that these changes should not be a handicap to women and students with fewer resources or difficulties in accessing the Internet.

It is clear that the incursion of women and girls into new technologies and science facilitates the elimination of the discrimination they have suffered throughout history and meets the goals of education for sustainability and the universalization of human rights. In this way, women and girls will have greater participation and representation in all social and political spheres, with complete training, without discrimination, and by making progress towards gender equality. Indeed, education for sustainable development requires that gender equality be a reality in all areas of society and a basic requirement for advancing education, science, and social and political institutions. Reasonably, we are facing a significant challenge demanded in the 2030 Agenda for Sustainable Development, encouraging the use of information and communication technologies to promote women's empowerment. As a result, progress will be made in eliminating inequalities among men and women, making gender equality and the empowerment of all women and girls a reality around the world.

\section{Limitations and Future Lines of Research}

The most important limitation of the research carried out underlines the small sample size. Currently, we are working with a much wider sample and in other universities, considering the effects that new methodologies that are being generated in face-to-face education can have on gender equality, with the introduction of online training modes and the enhancement of the use of technological tools. However, the studies consulted, so far, do not show significant discrepancies with the research developed in this article.

Author Contributions: Methodology, A.P.-R. and A.C.; conceptualization, A.P.-R., E.L.-P., and E.G.-T.; investigation, A.C. and E.L.-P.; validation, A.C., E.G.-T., and E.L.-P.; formal analysis, A.P.-R., A.C., and E.G.-T.; supervision, A.P.-R.; review and editing, A.P.-R., E.L.-P., and E.G.-T.; data curation, E.G.-T., A.C., and E.L.-P.; funding acquisition, A.P.-R. All authors have read and agreed to the published version of the manuscript.

Funding: Support has been received from the EDUCALITY Research Group (GRIN 28815) and the Scientific Research and Technology Transfer Project (SBPLY/000149) funded by the Ministry of Education, Culture of CLM, and European Regional Development Funds (ERDF).

Conflicts of Interest: The authors declare no conflict of interest.

\section{References}

1. Zhou, L.; Li, F.; Wu, S.; Zhou, M. "School's Out, But Class's On", The Largest Online Education in the World Today: Taking China's Practical Exploration During The COVID-19 Epidemic Prevention and Control as An Example. Best Evid. Chin. Edu. 2020, 4, 501-519. [CrossRef]

2. Wang, Z.; Wu, Y.; Liu, S.; Online Learn-Ing Promotes Teaching Model Reform. Chin Edu Daily. Available online: http://www.chinadaily.com.cn/edu/index.html (accessed on 27 March 2020). 
3. Adell, J.; Castañeda, L. Tecnologías emergentes, ¿pedagogías emergentes? In Tendencias Emergentes en Educación con TIC; Hernández, J., Pennesi, M., Sobrino, D., Vázquez, A., Eds.; Asociación Espiral, Educación y Tecnología: Barcelona, Spain, 2012; pp. 13-32.

4. Badia, A.; Meneses, J.; Sigalés, C. Percepción de los docentes sobre los factores que afectan al uso educativo de las TIC en el aula equipada de tecnología. Electr. J. Res. Educ. Psych. 2013, 11, 787-808.

5. Catasús, M.G.; Romeu, T.; Pérez-Mateo, M. Competencias TIC y trabajo en equipo en entornos virtuales. Rusc. Univ. Knowl. Soc. J. 2007, 1, 4.

6. Plan de Acción para la Implementación de la Agenda 2030. Hacia una Estrategia Española de Desarrollo Sostenible. Available online: https://sustainabledevelopment.un.org/content/documents/20119Spain_Annex_ 1__PLAN_DE_ACCION_AGENDA_2030_002.pdf (accessed on 14 January 2020).

7. Pérez, P.; Andino, S. Las Desigualdades de Género en el Sistema Público Universitario Vasco; Emkunde: Vitoria-Gasteiz, Spain, 2003.

8. Pérez, E. La Situación de las Mujeres en el Sistema Educativo de Ciencia y Tecnología en España y su Contexto Internacional. Available online: https://www.ohchr.org/Documents/Issues/CulturalRights/ ConsultationEnjoyBenefits/UNESCOLASITUACIaNDELASMUJERESENELSISTEMA.pdf (accessed on 4 December 2019).

9. Sáinz, M.; López-Sáez, M. Gender differences in computer attitudes and the choice of technology-related occupations in a sample of secondary students in Spain. Comput. Educ. 2010, 54, 578-587. [CrossRef]

10. Sanz, V. Women and computer engineering: The case of the school of computer science at the technical university of Madrid. Arbor 2008, 905-915. [CrossRef]

11. Burrelli, J. Thirty-Three Years of Women in SEE Faculty Positions. National Science Foundation Positions (NSF 08-308); National Science Foundation: Washington, DC, USA, 2008.

12. Carlson, S. Wanted: Female computer scientists. Chron. High. Educ. 2006, 52, 35-38.

13. McGrath, J. Recruiting and retaining women in undergraduate computing majors. ACM SIGCSE Bull. 2001, 44, 108-114.

14. Millar, J.; Jagger, N. Women in ITEC Courses and Career; Final Report; SPRU, University of Sussex: Birmingham, UK, 2001.

15. Porter, L.V.; Sallot, L.M. The internet and public relations: Investigating practitioners' roles and world wide web use'. Journal. Mass Commun. Q. 2003, 80, 603-622. [CrossRef]

16. Castaño, C.; González, A.M. La disparidad entre la participación y la posición de las mujeres en la investigación TIC: El caso del Plan Nacional de I+D+i. Rev. Madri+D 2008, 21, 118-126.

17. Gil-Juárez, A.; Feliu, J.; González, A.V. Performatividad Tecnológica de Género: Explorando la Brecha Digital en el mundo del Videojuego. Quad. Psicol. 2010, 12, 209-226. [CrossRef]

18. Gil-Juárez, A.; Vitores, A.; Feliu, J.; Vall-Llovera, M. Brecha digital de género: Una revisión y una propuesta. Rev. Teor. Educ. 2011, 12, 25-53.

19. Gil-Juárez, A.; Feliu, J.; Vitores, A. Género y TIC: En torno a la brecha digital de género. Athenea Digit. 2012, 12, 3-9. [CrossRef]

20. Kekelis, L.S.; Ancheta, R.W.; Heber, E. Hurdles in the pipeline: Girls and technology careers. Front. A J. Women Stud. 2005, 26, 99-109. [CrossRef]

21. Beavis, C.; Charles, C. Would the 'real' girl gamer please stand up? Gender, LAN cafés and the reformulation of the 'girl' gamer. Gend. Educ. 2007, 19, 691-705. [CrossRef]

22. Kafai, Y. Video game designs by girls and boys: Variability and consistency of gender differences. In From Barbie to Mortal Kombat: Gender and Computer Games; Cassell, J., Jenkins, H., Eds.; MIT Press: Cambridge, UK, 1998; pp. 90-117.

23. Margolis, J.; Fisher, A. Unlocking the Clubhouse. Women in Computing; MIT Press: Cambridge, UK, 2002.

24. Royse, P.; Lee, J.; Undrahbuyan, B.; Hopson, M.; Consalvo, M. Women and Games: Technologies of the Gendered Self. New Media Soc. 2007, 9, 555-576. [CrossRef]

25. Schott, G.R.; Horrell, K.R. Girl Gamers and their Relationship with the Gaming Culture. Convergence 2000, 6, 36-53. [CrossRef]

26. Subrahmanyam, K.; Greenfield, P.M. Computer games for girls: What makes them play. In From Barbie to Mortal Kombat: Gender and Computer Games; Cassell, J., Jenkins, H., Eds.; MIT Press: Cambridge, UK, 1998; pp. 46-71.

27. Thornham, H. "It's a boy thing": Gaming, gender and geeks. Fem. Med. Stud. 2008, 8, 127-142. [CrossRef] 
28. Walkerdine, V. Playing the game: Young girls performing feminity in video game play. Fem. Med. Stud. 2006, 6, 519-537. [CrossRef]

29. Eurostat. Students Enrolled in Tertiary Education by Education Level, Programme Orientation, Sex and Field of Education. Available online: https://ec.europa.eu/eurostat/data/database?node_code=educ_uoe_enrt03 (accessed on 6 November 2019).

30. Bisquerra, R. Metodología de la Investigación Educativa; La Muralla: Madrid, Spain, 2004.

31. Booth, S.; Goodman, S.; Kirkup, G. Gender Differences in Learning and Working with Technology: Social Constructs and Cultural Contexts; IGI Global: Hershey, PA, USA, 2010.

32. Brynin, M. The Neutered Computer. In Computers, Phones and the Internet; Kraut, R., Brynin, M., Kiesler, S., Eds.; Oxford University Press US: Oxford, UK, 2006; pp. 84-96.

33. Castaño, C. La Segunda Brecha Digital; Ediciones Càtedra: Madrid, Spain, 2008.

34. Trauth, E.M.; Nielsen, S.H.; von Hellens, L.A. Explaining the IT gender gap: Australian stories for the new millennium. J. Res. Pract. Inf. Technol. 2003, 35, 7-20.

35. Black, S.E.; Jameson, J.; Komoss, R.; Meehan, A.; Numerico, T. Women in Computing: A European and International Perspective. In Proceedings of the 3rd European Symposium on Gender \& ICT: Working for Change, Manchester, UK, 1 February 2005.

36. Sanz, V. Mujeres e Ingeniería Informática: El caso de la Facultad de Informática de la UPM. Arbor 2008, 184, 905-915. [CrossRef]

37. Turner, S.V.; Brent, P.W.; Pecora, N. Why Women Choose Information Technology Careers: Educational, Social, and Familial Influences; Annual Educational Research Association: New Orleans, WA, USA, 2002.

38. Adya, M.; Kaiser, K.M. Early determinants of women in the it workforce: A model of girls' career choices. Inf. Technol. People 2005, 18, 230-259. [CrossRef]

39. Ahuja, M.K. Women in the information technology profession: A literature review, synthesis, and research agenda. Eur. J. Inf. Syst. 2002, 11, 20-34. [CrossRef]

40. Beise, C.; Myers, M.; VanBrackle, L.; Chevli-Saroq, N. An examination of age, race, and sex as predictors of success in the first programming course. J. Inf. Educ. Res. 2003, 5, 51-64.

41. Chinn, D.; Vandegrift, T. Gender and diversity in hiring software professionals: What do students say? In Proceedings of the Fourth International Workshop on Computing Education Research, ICER'08, Sidney, Australia, 6-7 September 2008; Association for Computing Machinery: New York, NY, USA, 2008; pp. 39-50.

42. Clegg, S.; Trayhurn, D. Gender and Computing: Not the same old problem. Br. Educ. Res. J. 2000, 26, 75-89. [CrossRef]

43. Cuny, J.; Aspray, W. Recruitment and Retention of Women Graduate Students in Computer Science and Engineering; Computing Research Association: Washington, DC, USA, 2000.

44. Galpin, V. Women in Computing around the world. ACM SIGCSE Bull. 2002, 34, 94-100. [CrossRef]

45. Hayes, E. Girls, gaming, and trajectories of technological expertise. In Beyond Barbie and Mortal Kombat: New Perspectives on Gender and Gaming; Kafai, Y., Heeter, C., Denner, J., Sun, J., Eds.; MIT Press: Cambridge, UK, 2008; pp. 217-229.

46. Jenson, J.; De Castell, S. Her own boss: Gender and the pursuit of incompetent play. In En Changing Views: Worlds in Play, Proceedings of Digital Games Research Association Conference, Vancouver, Canada, 16-20 Junuary 2005; University of Vancouver: Vancouver, Canada, 2005.

47. Roberts, D.F.; Foehr, U.G.; Rideout, V.J. Generation M: Media in the Lives of 8-18-year olds; Kaiser Family Foundation Study: Menlo Park, CA, USA, 2005.

48. Jenson, J.; De Castell, S. Gender, Simulation and Gaming: Research review and redirections. Simul. Gaming 2010, 41, 51-71. [CrossRef]

(C) 2020 by the authors. Licensee MDPI, Basel, Switzerland. This article is an open access article distributed under the terms and conditions of the Creative Commons Attribution (CC BY) license (http://creativecommons.org/licenses/by/4.0/). 